\title{
Anatomical and Histological Lesions Causing infertility in Local Goats ( Sulaimania Region).
}

\author{
A.F. AL-wan \\ F. AS. Amine \\ Coll.Vet.Med.Uni.of Baghdad. \\ Coll.Vet.Med. Uni.of Al-Sulaimania.
}

\begin{abstract}
The study was conducted on 103 samples of female goats genitalia which included Fifty cases of non-contain fetus and 53 cases of contain fetus goat genitalia. These cases were collected from a new slaughter house in Sulaimani region. Gross abnormalities of the genital tract in non-contain fetus genital were noted in $8(16 \%)$ with total of 18 abnormalities lesions. Ovaro-bursal adhesions were noted in $2(4 \%)$,follicular cystic ovaries $2(4 \%)$ and para-ovarian cysts $1(2 \%)$.Oviduct lesion 5(10\%),While the uterine lesions were 6 (12\%) Histopathological sections of the oviducts showed the presence of edema and inflammatory cells with sloughing of the epithelial cells, whereas the uterine infections in non-pregnant does were histopathologically characterized by the presence of mononuclear cells infiltration (macrophage and lymphocyte) in uterine layers. Gross abnormalities of the genitalia contain fetus were noted in 5(9.42\%). Ovarobursal adhesions are the most common conditions 3(5.66\%), Para-ovarian cysts 1(1.88\%). Congenital dropsy (the congenital abnormality) was (1.88\%) in genitalia contain fetus.It was coneluted that ovaro-bursal adhesions are the most common gross abnormality, as well as the congenital and anatomical abnormalities which cause sterility and /or infertility in Sulaimamia region leading to slaughtering the goat . Goats were showed less seasonality and breed throughout the year.
\end{abstract}

\section{Introduction}

Goats are fertile small ruminants bred in large numbers in Sulaimani Region, they are used mainly for the production of milk, meat, hair, and skin, but there have been very few studies on the causes of infertility and reproductive aspects of goats in the region. Genital abnormalities play an important role in animal breeding either by causing infertility or sterility (1). Abattoirs provided a useful source of information on the types and prevalence of genital tract lesions and abnormalities( 2 and 3).Ovarobursal adhesion is considered as one of the most common complicated pathological

\section{Materials and Methods}

The study was conducted on 103 samples of goat genitalia, of them50 samples of non-contain fetus and 53 samples of contain fetus genitalia of goats. These samples were collected once weekly from a new slaughter house in Sulaimani, during the period from June 2007 to the end of May 2008. The slaughtered goat breed were mostly local Karadi goats (7). The age of the animals was ranged from 2-5 years and no abnormalities found in the abattoir studies, a large proportion of ovaro-bursal adhesions result from ascending uterine infections (4 and5) . Histologically, endometrial infiammation is characterized by desquamation and necrosis of superficial epithelium, congestion and presence of inflammatory cells (6). The present study is designed to found out the reproductive problems causing infertility in goat reproduction. As well as, the congenital and anatomical abnormalities which cause sterility and/or infertility in Sulaimania region leading to goat slaughtering.

information regarding the identity of the animals was available. Immediately after evisceration at the slaughter house, the genitalia were separately placed in plastic bags and transported to a laboratory of Veterinary Teaching Hospital at the College of Veterinary Medicine. The genital samples were divided into contain and not-contain foetus samples by external palpation. The fresh specimens were carefully examined 
before spread and the organs were freed of extraneous tissues. Macroscopic abnormalities of the Ovaries were examined for any adhesions or abnormal lesions then photographed by a digital camera, abnormalities of the ovaries were diagnosed in the laboratory of pathology, then the bursa were examined carefully for the presence of adhesions. Uterine tubes were examined, according to(8), carefully for detection of occlusion by injecting coloured normal saline near their junction with the

\section{Result}

The total number of 50 non-contain fetus genitalia of goats was examined, of them $8(16 \%)$ were with one or more abnormal lesions with total lesions macroscopically observed were $18(36 \%)$ (table 1).

The distribution of the lesions in the cases were as follows:

One case showed 5 abnormal lesions:

1- severe Ovaro-bursal adhesions

2- pyosalpinx 3-Salpingitis

4- uterine adhesions

5- metritis and endometritis

Each of 6 cases showed the following two abnormalities :

1-a-follicular cystic ovary b-Metritis and endometritis

2- a- occlusion of the oviduct b- Mucometra 3-a- salpingitis b- Pyosalpinx

4- a- paraovarian cysts b- Cystic corpus luteum

5- a- endometritis b-Cervicitis

6- a- follicular cystic ovary b- Pyometra

Six $(12 \%)$ out of 18 abnormalities were found in or around the ovaries of nonpregnant genitalia. Ovaro-bursal adhesions were observed in $2(4 \%)$ of the total genitalia examined. All the adhesions were bilateral and severe(table1), in which the ovaries were completely embedded in fibrous tissues. Follicular cystic ovaries were seen in 2(4\%) genitalia examined (Fig 1), the cysts contained clear fluid and had a thin wall. All the cases of follicular cysts were unilateral and single (1 right side and 1 left side). The dimensions and the weight of the left ovary uterine horns then free flow of the fluid from the fimbriated end was considered indicative of non obstructed tubes.Macroscopically investigation of gross abnormal conditions and their types were recorded in uterus and tissue samples sections of approximately $2 \mathrm{~cm}$.in length obtained from affected parts were fixed in a plastic container that contains $10 \%$ neutral buffered formalin for histopathological evaluation According to (9).

with follicular cysts were $3 \mathrm{~cm}$ length, $2 \mathrm{~cm}$ width, $1.5 \mathrm{~cm}$ thickness, and $5.955 \mathrm{gm}$ weight, while the dimensions and weight of the right ovary with follicular cysts were $2.5 \mathrm{~cm}, 1.5 \mathrm{~cm}, 1 \mathrm{~cm}$, and $4.955 \mathrm{gm}$, respectively. One (2\%) case of the Para ovarian cysts was located in the left side, it was attached to the anterior poles of the ovary. Its length was about $1 \mathrm{~cm}$, the width was $0.7 \mathrm{~cm}$ (fig 2). Cystic corpus luteum was seen in $1(2 \%)$ in the right ovary. cystic corpus luteum was grossly undifferentiated from the non-cystic; however, on palpation, it felt softer with a central cavity. The diameter of cystic corpus luteum was $1 \mathrm{~cm}$, while the diameter of the central cavity was $0.6 \mathrm{~cm}$. A total gross lesion of goats oviducts was $5(10 \%)$ of the total goat genitalia. Salpingitis was found in 2(4\%) cases (Fig 3), the lesions were observed in both sides, there was clear congestion, enlargement and thickening in the walls, and the cases were accompanied by pyosalpinx, metritis and endometritis, ovaro-bursal adhesions, and uterine adhesions. Pyosalpinx was found in $2(4 \%)$ cases and the lesions were observed in both sides. The oviduct became distended with pus. One specimen 1(2\%) showed bilateral occlusion of the oviduct. In this study occluded oviduct refers to tubes which were macroscopically normal in shape, color and consistency.Seven lesions (14\%) of total genitalia examined. Metritis and endometritis were found in 3(6\%) from the total genitalia (Fig 4). They were grossly characterized by hyperemic and edematous 
AL-Qadisiya Journal of Vet.Med.Sci Number of $4^{\text {th }}$ conference 24-25 Nov. 2010

that lead to enlargement and increasing of thickness of the uterus. Pyometra was found in $1(2 \%)$ genitalia grossly characterized by the accumulation of purulent exudates within the uterus with persistence of the corpus luteum. One $(2 \%)$ case of uterine adhesion was observed (Fig 3) characterized by fibrous adhesions between the uterus and other organs. One $(2 \%)$ case of mucometra was observed, it was grossly characterized by accumulation of clear fluid with the persistence of corpus luteum. Cervicitis was found in one (2\%) genitalia grossly characterized by hyperemia and edematous and it is rigid in touch.

Table 1: Incidence of Various Gross Abnormalities in Non-Pregnant Goats.

\begin{tabular}{|l|l|l|l|l|l|l|}
\hline abnormalities & $\begin{array}{l}\text { R. side } \\
\text { no. }\end{array}$ & $\begin{array}{l}\text { L. side } \\
\text { no. }\end{array}$ & $\begin{array}{l}\text { Both } \\
\text { sides }\end{array}$ & $\begin{array}{l}\text { Total } \\
\text { no. }\end{array}$ & $\begin{array}{l}\text { Abnormalities } \\
\text { percentage } \\
\text { N=18 }\end{array}$ & $\begin{array}{l}\text { Total } \\
\text { percentage } \\
\text { N=50 }\end{array}$ \\
\hline $\begin{array}{l}\text { Ovaro-bursal } \\
\text { adhesion }\end{array}$ & - & - & 2 & 2 & 11.11 & 4 \\
\hline $\begin{array}{l}\text { Follicular cystic } \\
\text { ovaries }\end{array}$ & 1 & 1 & - & 2 & 11.11 & 4 \\
\hline Paravarian cysts & - & 1 & - & 1 & 5.5 & 2 \\
\hline $\begin{array}{l}\text { Cystic corpus } \\
\text { luteum }\end{array}$ & 1 & - & - & 1 & 5.5 & 2 \\
\hline salpingitis of & - & - & 2 & 2 & 11.11 & 4 \\
\hline pyosalpinx and & - & - & 2 & 2 & 11.11 & 4 \\
\hline $\begin{array}{l}\text { Occlusion } \\
\text { oviduct }\end{array}$ & - & 1 & 1 & 5.5 & 2 \\
\hline $\begin{array}{l}\text { Metritis } \\
\text { endometritis }\end{array}$ & - & - & 1 & 1 & 5.5 & 6 \\
\hline pyometra & - & - & 1 & 1 & 5.5 & 2 \\
\hline Uterine adhesions & - & - & 1 & 1 & 5.5 & 2 \\
\hline mucometra & - & - & 1 & 1 & 5.5 & 2 \\
\hline cervicitis & - & 2 & 14 & 18 & & 2 \\
\hline total & & & 3 & 16.6 & 36 \\
\hline
\end{tabular}

$*$ total abnormalities $=18$

$*$ total genitalia affected $=8$ 
Table 2: The Incidence of Various Abnormalities in Pregnant Goat Genitalia

\begin{tabular}{|l|l|l|l|l|l|l|}
\hline Abnormalities & $\begin{array}{l}\text { Right side } \\
\text { No. }\end{array}$ & $\begin{array}{l}\text { Left side } \\
\text { No. }\end{array}$ & $\begin{array}{l}\text { Both } \\
\text { sides No. }\end{array}$ & $\begin{array}{l}\text { Total } \\
\text { No. }\end{array}$ & $\begin{array}{l}\text { abnormal } \\
\text { specimen } \\
\text { Percentage } \\
\text { (n=5) }\end{array}$ & $\begin{array}{l}\text { Total } \\
\text { specimen } \\
\text { Percentage } \\
(\mathrm{n}=53)\end{array}$ \\
\hline $\begin{array}{l}\text { Mild ovaro- } \\
\text { bursal } \\
\text { adhesions }\end{array}$ & - & 2 & 1 & 3 & 60 & 5.66 \\
\hline $\begin{array}{l}\text { Para ovarian } \\
\text { cysts }\end{array}$ & 1 & - & - & 1 & 20 & 1.88 \\
\hline $\begin{array}{l}\text { Congenital } \\
\text { dropsy and } \\
\text { anasarca }\end{array}$ & - & - & 1 & 1 & 20 & 1.88 \\
\hline Total & 1 & 2 & 2 & 5 & 100 & 9.42 \\
\hline
\end{tabular}

\section{Histopathological Study:}

Histopathological examination was done to abnormal specimens of non-contain fetus genitatia. Figure 5, Ovary of the doe, the histopathological sections also showed the spaces surrounded by homogenize connective tissue, layers of granulose, theca cells, and fibroblast

Diagnosis: Follicular Cystic Ovary

Goat ovary with para ovarian cyst. Histopathological (Fig. 5) referred cyst filled with proteinous material and lined by simple, flatted and epithelium cells arrested on fibrous connective tissues.Diagnosis:Para Ovarian Cyst.Sections through nodules around goat oviduct (Fig. 6) showed the presence of proteinous fluid lined by flatten epithelial layer arrested on fibrous connective tissue.

Diagnosis : Para Ovarian Cyst.

Histological section (Fig4) goat uterus suffering from lesion suspected endometritis (Fig 7). Histopathological section of the uterus of non-pregnant goat showed mononuclear cells infiltrations in the stroma of endometritis and uterine glands as well as blood vessels with inflammatory cells in their lumen.

\section{Discussion}

Anatomical and pathological abnormalities of female genitalia of goats were considered generally as a main cause of infertility or
Diagnosis: Acute non- Suppurative Endometritis.

Figure 8 histological study of non-pregnant goat uterus describe infiltration of mononuclear cells, macrophage and lymphocyte between muscle fibers and blood vessels.

Diagnosis: Sub-Acute Non-Suppurative Metritis

The total number of pregnant genitalia of goats was 53, gross abnormalities were noted in $5(9.42 \%)$ genitalia (table 2). Ovarobursal adhesions, the most commonly recorded condition, were noted in $3(5.66 \%)$ genitalia. All the adhesions were mild with slight connective tissue strands and most of them were unilateral. Only one case was affected bilaterally and 2 cases were affected unilaterally (left side). Para ovarian cysts were seen in one $(1.88 \%)$ of the pregnant genitalia (right side). The cysts were spherical in shape and about $0.5-0.8 \mathrm{~cm}$ in size, they were attached mostly to the anterior poles of the ovaries. One $(1.88 \%)$ genitalia contained fetal congenital dropsy or anasarca (congenital abnormalities), their length was $17 \mathrm{~cm}$, and the weight was $210 \mathrm{gm}$, it was characterized by massive generalized subcutaneous edema.

sterility that leads to the reduction of the reproduction efficiency and causes great economic losses in sheep and goats in 
Sulaimani region.The results in table 1 showed that the total incidence of macroscopic genital abnormalities reached $8(16 \%)$ in non-contain fetus genitalia, which showed one or more abnormalities. The incidence of gross abnormalities, was higher than that recorded by other workers(1,10and11). There is a great difference in the incidence of gross abnormalities found in the various areas and this might be attributed to the differences in breed, species, age, management of animals, and the source of genitalia frequency of pregnancy, and veterinary service. While , the total incidence of ovaro-bursal adhesions reached to $(4 \%)$ which was similar to that reported by (11) and higher than that of (1). The results of this study revealed that all the adhesions were bilateral and severe, which considerably influence fertility of the affected goats by limiting the movement of the fimbriae, The present work agrees with suggestion of other observation (12 and 13). Large proportion of the ovaro-bursal adhesions results from ascending uterine infections. These infections were often resulted from postpartum complications like retained fetal membranes, Metritis and Endometritis. The incidence of Para ovarian cyst reached to $(2 \%)$ in nonpregnant goats from total gross abnormalities, these results were similar to those reported by others (14 and 15), and lower than those recorded (1,16 and 17).On the other hand these results were higher than those recorded by others (5 and18). This type of cysts did not affect the reproductive fertility of the goats, unless it causes a pressure on the oviduct. Cystic ovaries were present in (2\%), follicular cystic ovaries (Fig 1) were present in $(4 \%)$, this result was similar to those reported by (11), but higher than that of (1and10). In this study, follicular cystic ovary was unilateral and single, this result agrees with that of (10). the incidence of follicular cystic ovaries might be attributed to insufficient release Luteinizing hormone prior to or at the time of ovulation.Follicular cystic ovaries are characterized by the presence of spaces surrounded by homogenized connective tissues with a layer of theca cells and fibroblast (Fig. 5).The total prevalence of Salpingitis reached to $(4 \%)$ in non-contain fetus, these findings are higher than those of (1) in goats, The lesions were observed in both sides and they were accompanied by pyosalpinx, metritis, endometritis, cervicitis, and ovaro-bursal adhesions could be due to the infectious agents enter the uterine tube via the uterus, a similar observations was described by (19). Salpingitis was characterized by enlargement and thickening in the walls of uterine tube (Fig 3) which come in agreement with the same result of (20). The prevalence rate of occlusion of uterine tubes was $(2 \%)$ from the total gross abnormalities in non-contain fetus genitalia these results are lower than those of reported by other workers (1, 14, 16 and 19). Occlusion of the lumen of the uterine tube affected bilaterally and certainly affected the fertility of the goats by preventing passage and fertilized of ova by spermatozoa.Hydrosalpinx developed as a sequelae to Salpingitis (2) and the prevalence of Hydrosalpinx in the present study reached to $(2 \%)$ and was higher than the results recorded by (21). Hydrosalpinx was characterized by the distension of the uterine tube and the distended tube was a thin-walled elongated and fluctuated on palpation (Fig 3).The total incidence of pyosalpinx reached to $(4 \%)$ from the total macroscopic abnormalities in non-pregnant goats.They were higher than those recorded by (1 and14). Pyosalpinx occurs following severe uterine infections and this agrees with the suggestion of (22). Most of the uterine lesions were of inflammatory origin, the present study showed that the results of the (6\%) in non-contain fetus (Fig 4). The results of this study were higher than those reported by(23) and lower than those of Ali (17). The uterine infections are likely to follow abnormal parturition, rough manipulation, retention of the fetal membrane and delayed involution of the 
uterus or may occur following coitus which leads to occlusion of uterine tube that affects fertility and lead to infertility or sterility of the animal.The total incidence of pyometra in non-pregnant goats reached to $(2 \%)$, these results were higher than those recorded by (1 and 19) and lower than those of(23). Most of the cases of pyometra which have been recordedduring this work appeared as accumulation of purulent exudates within the uterus with persistence of a corpus luteum and pyometra which were sequel to uterine infection during breeding season .The incidence rate of cervicitis in non-pregnant goats reached to $(2 \%)$. The results were higher than those recorded by Al-Zebary (23). In this study the chronic cervicitis was characterized by fibrosis and obstruction of the cervical canal. Mucometra was found in $(2 \%)$ in non-pregnant goats, this result was higher than that recorded by (1). It is characterized by an accumulation of a clear fluid that leads to distension of the uterus with persistence of corpus luteum .Uterine adhesions were found in $(2 \%)$ in nonpregnant goats, and that was higher than the result of (23). This increase in the incidence of macroscopic abnormalities in goats in Sulaimani region is probably due to many factors involved such as: bad management, poor sanitation, poor housing, low nutrition level, and increased contamination level of the environment.

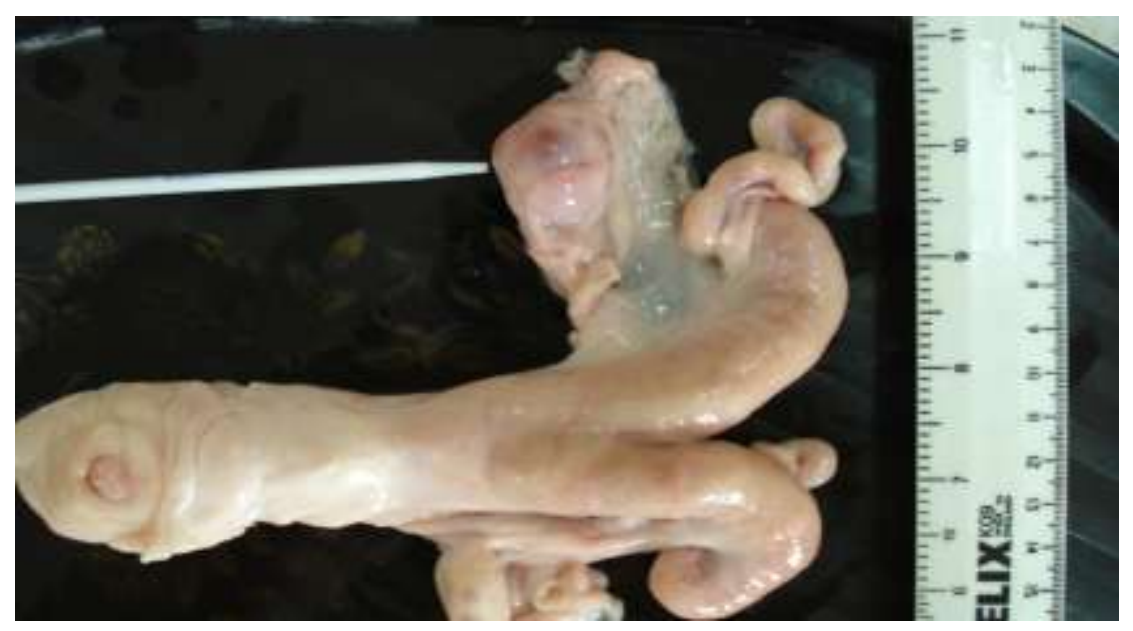

Figure 1: Goat genital Tract, Shows Ovary with Follicular Cystic and

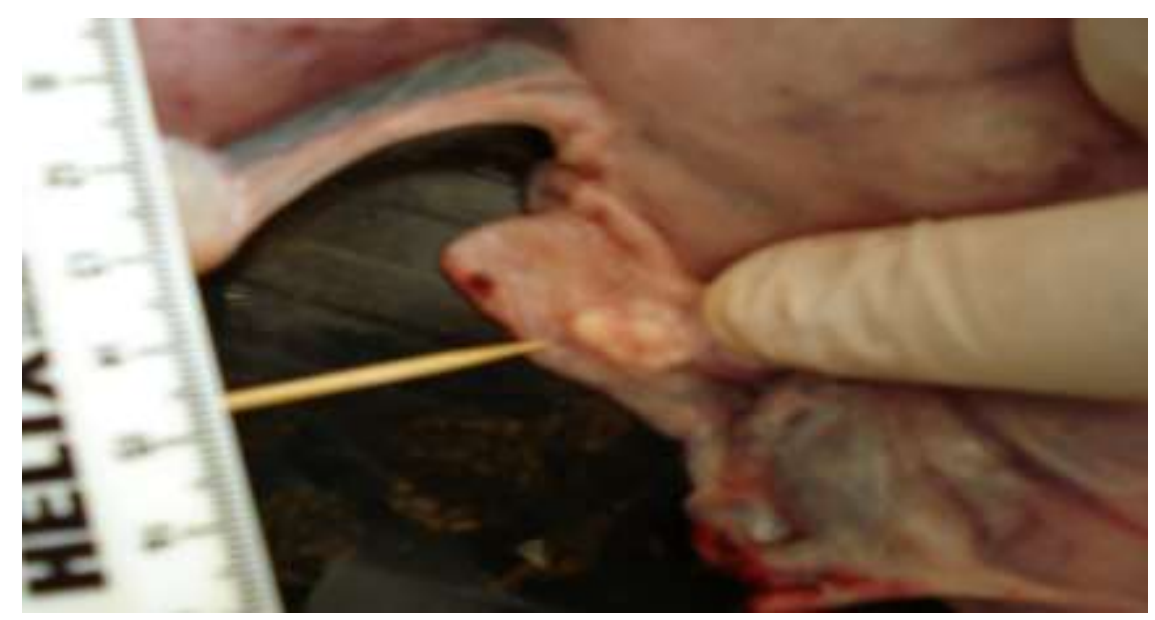

Figure2: Goat Ovary, With Paraovarian Cyst. 


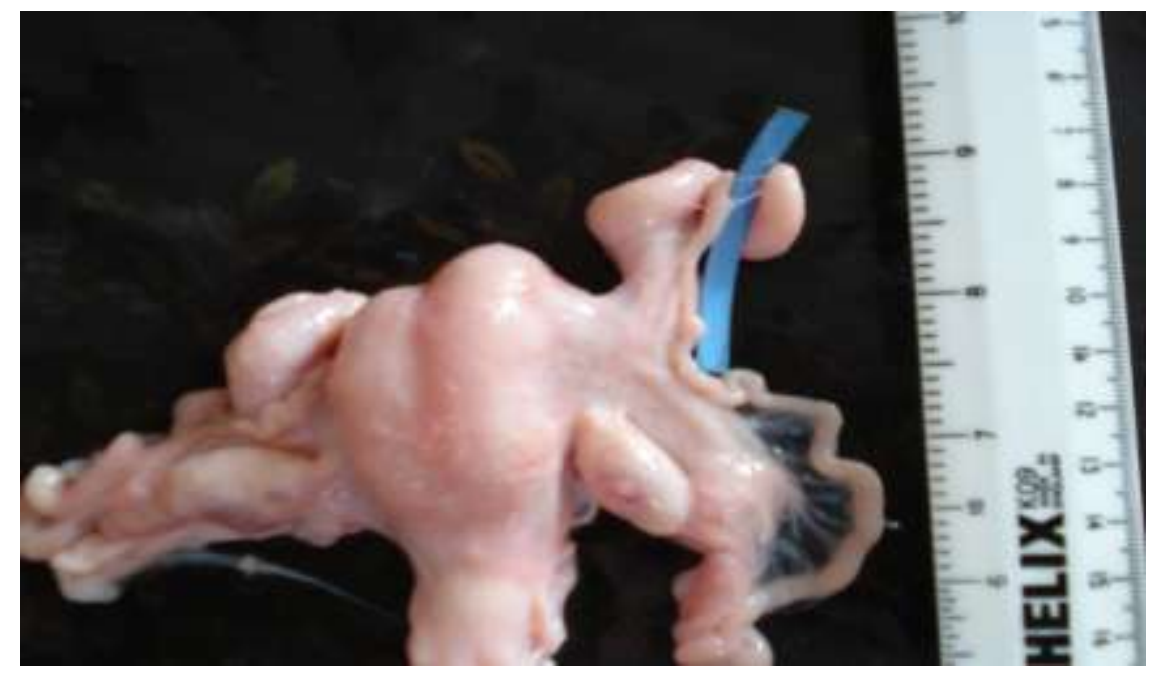

Figura 3: Goat genital shows salpingitis and uterine pathological lesions.

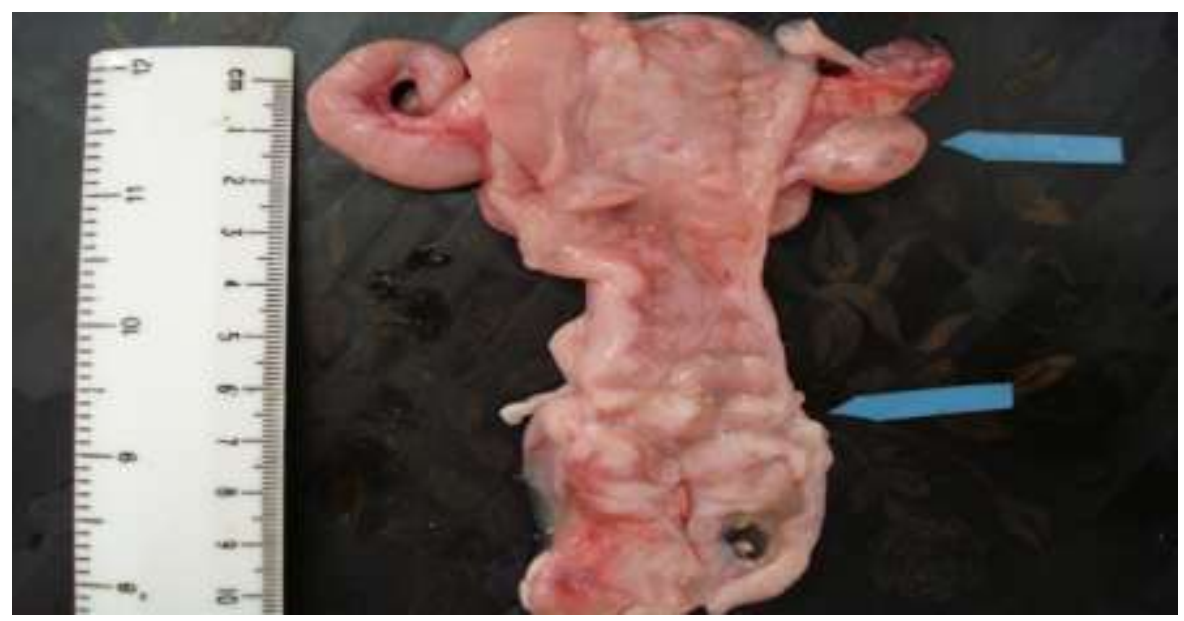

Figura 4: Goat uterus shows endometritis lesions.

\section{References}

1. Al-Baggal,H.A.R., Al-Dahash, S.Y.A. and Alwan, A.F. (1993). Macroscopic Study of the Female Genital System in Iraqi Goats.Small Ruminant Research, 9:341-346.

2. Kessy, B.M. and Noakes, D.E., (1985). Uterine TubeAbnormalities as a Cause of Bovine Infertility. Vet. Record,117:122-124.

3. Alwan, A.F., Al-Dahash, S.Y.A. and AlBaggal,H.A.R.(1993). Macroscopic Study of the Pregnant Genitalia of Iraqi Goats. Small Ruminant Research. 11: 343-349.
4. Lyngset, O., (1968d). Studies on Reproduction in the Goat. The Functional Activity of the Uterine Horns of the Goat. Acta. Vet. Scand. 9 : 308-315.

5. Al-Rawi,B.T.G.,(2006). Morphological and Histopathological Study of Goats' Ovary. M. Sc. Thesis, Coll. Agricul.Al- Anbar University.

6. Timurkaan N. and Karadas E.(2000). Morphological investigations on pathological changes of the female reproductive organs in goats.11uterus, cervix and vagina, F.U.Sag.Bil. Derg.14:209-220. 
7. Gall , C.(1996).Goat breeds of the word. Bohler Verlag, Wurzburg, Germany. B.P 79.

8. Akbar A.M.A.and Alwan A.F.(1990). Biometrical study on oviduct and their abnormalities in Iraqi local breed cows. Iraqi J Vet. Sci.4: 4546. Uni.Iraq.

9. Luna L.G. (1968). Manual of Histological Staining Methods of the Armed Forces Institute of Pathology. $3^{\text {rd }}$ Edt. MCGraw-Hill Book Com.New York.

10. Lyngset, O., (1968e). Studies on Reproduction in the Goat. Pathological Conditions and Malformation of the Genital Organs of the Goat. Acta. Vet. Scand. 9: 364-375.

11. Alwan, A.F.,(1998). Gross Abnormalities Affecting Female Genital Tracts of Iraqi Ruminants. The Veterinarian, 8(2): 23-29.

12. Majeed, A.F., and Taha, M.B.,(1995). Obstetrical Disorders and Their Treatment in Iraqi Awassi Ewes. Small Ruminant Research. 17:6569.

13. Amin, F.A.S.M.,(2001). Clinical and Abattoir Study of Reproductive Problems in Local Breed Cows in Sulaimani District. M.V. Sc. Thesis, College of Vet. Medicine, Sulaimani University.

14. Al-Ja'aferi, H.R.A.,(2002). Study of Some Infertility Causes of Ewes in Iraq .M. Sc., Thesis, College of Vet. Medicine, Baghdad University.

15. Sofee, S.A., (2008). Morphological and Histopathological Study of the Ovarian Activity in Local Breed Ewes with Special Reference to the Seasonal Effects. M. Sc. Thesis, college of Vet. Medicine, DohukUniversity.
16. Al-Ghureiri, K.D.A.M.(2005). A Macroscopical Study of Female Genitalia of Ewes. M. Sc. Thesis, College of Agriculture, AlAnbar University.

17. Ali, T.G.,(2006). Anatomical and Pathological Abnormalities of Non- Pregnant Genitalia in Karadi Ewes.Al-Anbar J. Agric.Sci. 4(1):7-11.

18. Sattar, A., Khan, M.Z., and Siddique, M., (1988). Incidence, Pathology, and Bacteriology of Abnormalities of Fallopian Tubes in goats. Pakistan Vet. J., 8 :14-17.

19. Al-Rawi, I.Y.I.(2004). Morphological and Histological study of Abnormal Cases of Female Reproductive System of Awassi Ewes in Ninavaha Province. M. Sc. Thesis, College of Vet.Medicine, Al-Mosul University.

20. Karadase, E., and Timurkaan, N.(1999). Pathomorphologic Investigations on the Genital System of Ewes I. Ovarium and Oviduct. Tr. J. vet. Anim. Sci., 23 :557-565.

21. Al-Dahash, S.Y.A., Alwan, A.F. and Ali, J.B.(1993). Gross Abnormalities Affecting Genital Tracts of Iraqi Ewes. International J. Anim. Sci., 26(1):60-61.

22. Kennedy, P.C.and Miller, R.P.(1993).The female genitial system.In:Juub,K.V.C.,Kennedy,P. V.C.and Pamer, N. Pathology of domestic Animals.Academic Prees, San Diego,3(4):349-454.

23. Al-Zebary,B.K.A.,(2008).Pathological and Histomorphological studies Of the Genital Tubular System of the Local Iraqi Ewes in Duhok Province. M. Sc., Thesis, College of Veterinary Medicine, Duhok University. 


\section{ألإصابات التشريحية المرضية و النسجية المسببة للعقم فى المعز المحلية ـمنطقة \\ السليما نية السية

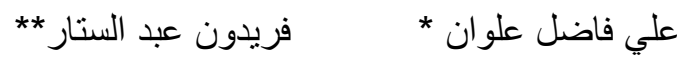 \\ * كلية الطب البيطري - جامعة بغداد. \\ | - ملية الطب البيطري - جامعة السليمانية.}

\section{الخلاصة}

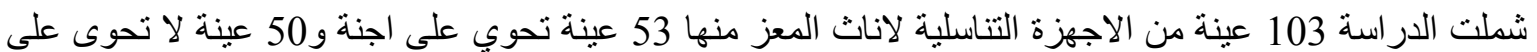

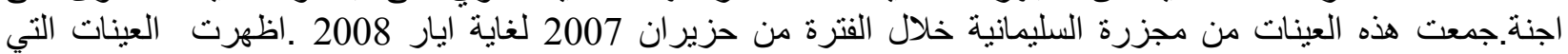

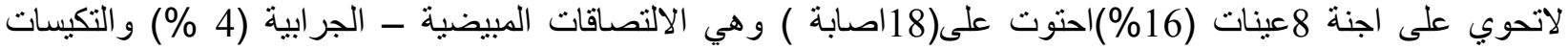

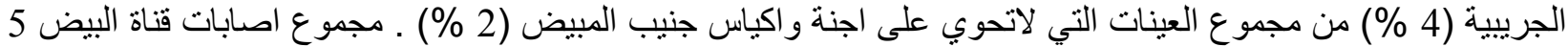

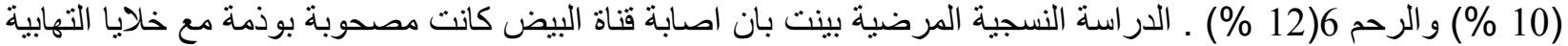

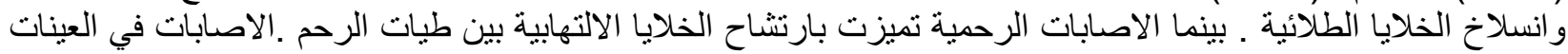

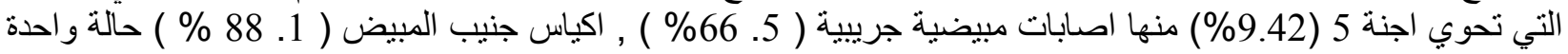
من التشوهات ـ وقد استنتج من الدراسة بان احد الاسباب المهمة لذبح المعز هي اصابات الجهاز التناسلي الانثوي المسبية 